Discussion: In 1978 Weiman and in 1990 Holmgren $^{1}$ had separately noted that workplace or work-related stress and stressors are the major reasons for such as sick-leave; physiological and psychological illnesses, work burnout and consequently these issues can cause the individual or organizational problems. We employed the Rice (1999) WPS self-esteemed questionnaire because we considered that our study participants will be categorized as relatively healthy, i.e. they never complain about being sick and leave the work. Furthermore, we decided that it would be reasonable if the participants assess themselves whether they are in work-related stress by reading and getting an idea what can be called workplace stress indeed $^{2}$.

It is clear that women dominate nursing around the world, however regardless of the work environment, requirements, or workload, regardless of gender all are exposed to workplace stress. The results of our study agree that it depends only on individuals. Our study gave proof that due to ANOVA the gender differences on workplace stress is absent $(\mathrm{F}=0.404),(\mathrm{p}=0,525)$ statistically. According to literature, workplace stress is often treated by the gender of nurses, but the results vary. Certain researchers noted that there is no gender difference in work stress 3 and others claimed that female nurses are more vulnerable to various occupational stresses than men4 moreover; some researchers figured out those female nurses are more intended for psychological stress; meanwhile the men tend to physiological stressors. 5 The results of this study are similar to the results of a 2013 study by Finnish researchers as well as Mauno that found that young nurses are less exposed to workplace stress than older nurses6. We agreed with the global studies that the nurses at younger age are less exposed to the work stress because they are working in a fellowship system and they are always relying on co-workers help. Particular researchers, such as Takase, Teraoka, and Yabase, suggested in a 2016 study that nurses over the age of twenty-five who want to keep their workplaces are more stressed than middle-aged and older nurses.7 The statistically significant differences in the stress levels $(F=1.923)$ and $(p=0.105)$. Above demonstrated results suggested that the onset of stress in a nurse's workplace depends on many different levels of social factors, such as age, gender, organizational characteristics, organization, place of work, and years of service. And these stressors have different impacts on individuals.

Conclusion: Nursing work-related stress levels were $\mathrm{F}=3.071, \mathrm{p}=0,028$; and it expressed statistical significant differences regarding the ANOVA analysis.

\title{
STUDY OF THE POSSIBILITIES OF PREOPERATIVE CHEMOTHERAPY IN MULTIPLE METASTASIS OF COLORECTAL CANCER IN THE LIVER
}

DOI: 10.31618/ESU.2413-9335.2020.1.77.958
Islamov Kh.D. ${ }^{\text {I } \text { Niyozova Sh.Kh. }{ }^{2}}$
${ }^{1}$ Republican Scientific and Practical Medical Center of Oncology
and Radiology of the Ministry of Health of the Republic of Uzbekistan
(RSSPMC OR MOH RUz),
${ }^{2}$ Tashkent medical academy

\section{SUMMARY}

Preoperative chemotherapy (CT) in 35 patients with colorectal cancer (CRC) with liver metastases demonstrated a high frequency of objective effects - in $22(62.9 \%)$ patients, stabilization was noted in $10(28.6 \%)$ cases. With bilobar liver metastases and the use of oxaliplatin-containing regimens, partial regression was $62.9 \%$. Side effects in most cases were clinically insignificant, no deaths were observed. The results obtained demonstrate the possibility of performing extended surgical operations in the majority of CRC patients with multiple liver metastases after preoperative CT.

Key words: colorectal cancer, liver metastases, preoperative chemotherapy

1

https://bmcpublichealth.biomedcentral.com/articles/10 .1186/s12889-019-7940-5/

${ }^{2}$ Rice, P. L. (1992). Stress \& Health (2nd ed.) Pacific Grove, California: Brooks/Cole Publishing Company. http://www2.uwstout.edu/content/lib/thesis/2000/2000braate nd.pdf - research paper

${ }^{3}$ Wong S., DeSantics G., Staudemayer N. The relationship between task interdependency and role stress: A revisit of the job demands-control model. J. Manage. Stud. 2007;44:284 303. doi: 10.1111/j.1467-6486.2007.00689.x. [CrossRef] [Google Scholar] [Ref list] 2. Proost K., de Witte H., de Witte K., Everts G. Burnout among nurses: Extending the job demand-control-support model with work-home interference. Psychologica Belgica. 2004;44:269-288. [Google Scholar] [Ref list])

${ }^{4}$ (1. Gunkel M., Lusk E., Wolf B., Li F. Gender specific effects at work: An empirical study of four countries. Gend.
Work Organ. 2007;14:56-79. doi: 10.1111/j.14680432.2007.00332.x. [CrossRef] [Google Scholar] [Ref list], 2. https://www.ncbi.nlm.nih.gov/pmc/articles/PMC3564148/,

${ }^{5}$ (Burke R. Work stress and women's health: Occupational status effect. J. Bus. Ethics. 2002;37:91-102. doi: 10.1023/A:1014734302972. [CrossRef] [Google Scholar] [Ref list])

${ }^{6}$ Mauno, S., Ruokolainen, M., \& Kinnunen U. (2013). Does aging make employees more resilient to job stress? Age as a moderator in the job stressor-well-being 127 relationship in three Finnish occupational samples. Aging \& mental health,17(4), 411-412. doi:10.1080/13607863.2012.747077

${ }^{7}$ Takase, M., Teraoka, S., \& Yabase, K. (2016). Retaining the nursing workforce: factorb contributing to the reduction of nurses' turnover intention in Japan. Journal of

Nursing Management, 24(1), 21-29. doi:10.1111/jonm.12266 
In recent decades, there has been an increase in incidence and mortality rates from colorectal cancer (CRC) throughout the world, including in Uzbekistan. The main target for metastasis in colorectal cancer is the liver due to unique portal drainage. In $15-30 \%$ of patients with newly diagnosed cancer of the colon or rectum, synchronous liver metastases are revealed, and in $50-75 \%$ of patients in subsequent years, secondary (metachronous) liver metastases are diagnosed. The average life expectancy of patients with unreleased CRC metastases is less than 1 year, and with synchronous metastases -4.5 months from the date of diagnosis $[1,2,3,8,11,17]$.

To date, liver resection has been the only treatment to achieve long-term survival in patients with liver metastases of CRC. However, only a small group of patients $(15-20 \%)$ can count on a potentially radical treatment, including removal of the primary tumor of the colon and liver resection. Traditional liver resection in operable patients allows a 5-year survival rate of 21$37 \%$ to be achieved $[4,12-16]$.

Currently, the standard treatment regimens for patients with colorectal cancer with liver metastases are cytotoxic drugs (oxaliplatin or irinotecan) in combination with 5-fluorouracil and leucovorin [7,10]. There is still no consensus on the effect of preoperative chemotherapy on postoperative complications. In a number of studies, no effect of preoperative chemotherapy on the postoperative course was found. On the other hand, many studies have shown a clinically significant prevalence of the incidence of postoperative complications in the group with preoperative chemotherapy in relation to the group of surgical treatment. Values range from $13-16 \%$ in the surgical treatment group and up to $25-37 \%$ in the neoadjuvant chemotherapy group $[6,18]$. In this case, preoperative chemotherapy can cause toxic damage to the liver, and thereby limit the resectability of the tumor, increasing the likelihood of postoperative complications, in particular, liver failure. The effect of preoperative chemotherapy is not so obvious in the case of a greater number of liver metastases (more than four), since at the moment there are no prospective data that could help in making a decision on prescribing chemotherapy [5,9,10, 19-22].

\section{The aim of the study}

To study the possibilities of modern preoperative chemotherapy regimens in the combined treatment of CRC metastases in the liver.

\section{Materials and methods.}

The present study included 35 patients with CRC with liver metastases who were examined and treated in the chemotherapy department of the Republican Scientific and Practical Medical Center of Oncology and Radiology of the Ministry of Health of the Republic of Uzbekistan in the period from 2018 to 2020. between the ages of 34 and 73. All patients had a morphologically verified diagnosis of colon adenocarcinoma after removal of the primary tumor. According to the morphological study, in 26 (74.3\%) patients, moderately differentiated adenocarcinoma prevailed, highly and poorly differentiated variants were encountered much less frequently - in $5(14.3 \%)$ and $4(11.4 \%)$ patients, respectively. Liver metastases met the following criteria of resectability: preservation of at least $25 \%$ of the liver parenchyma formed by at least two adjacent segments, with adequate bile duct and vascular blood supply. In the majority of patients $28(80.0 \%)$ were diagnosed with a primary metastatic process, in $7(20.0 \%)$ liver metastases were detected after colon resection in the period from 5.5 to 44 months, on average after $22 \pm 4.3$ months In most cases, $23(65.7 \%)$ patients had bilobar liver damage. The sizes of metastases varied from 0.3 to $12.7 \mathrm{~cm}$, and the number of metastases ranged from 1 to 15 (on average, $5.1 \pm 0.5)$. At the time of enrollment in the study, all patients were in satisfactory condition (WHO ECOG 01), normal hematopoiesis, liver and kidney indices, and no serious comorbidities.

In terms of combined treatment, all patients underwent preoperative chemotherapy for an average of $3.5 \pm 0.12$ months. followed by surgery. 32 (91.4\%) patients underwent preoperative chemotherapy with fluoropyrimidines and oxaliplatin (XELOX, CAPOX, FOLFOX); the remaining $3(8.6 \%)$ patients received the FOLFIRI regimen. The effect of chemotherapy was assessed by computed tomography (CT) data, every 68 weeks. treatment. The severity of side effects was determined using the NCI CTCAE Toxicity Scale, version 4.0 (2009).

Results and discussion.

After courses of preoperative chemotherapy, 27 $(77.1 \%)$ patients underwent radical surgery, the volume of which was determined by the initial metastatic lesion of the liver. More often than others, standard hemihepatectomy was performed - in 14 (51.9\%) of 27 patients, $11 \quad(40.7 \%)$ underwent extended hemihepatectomy, which included removal of the lobe and adjacent liver segments, and in $2(7.4 \%)$ patients, radical resection was limited to removal 1-3 liver segments.

All patients underwent a morphological examination of the surgical material. In no case were tumor cells found in the margin of liver resection. Signs of grade I drug pathomorphosis were detected in 5 $(18.5 \%)$ cases; II degree - in $10(37.0 \%)$ cases; III degree - 7 (25.9\%) and IV degree - $3(11.1 \%)$. In 2 (7.4\%) patients with disease progression on the background of CT, no signs of therapeutic pathomorphosis were found in the surgical material.

The postoperative management tactics were developed depending on the primary prevalence of the disease, the direct response to $\mathrm{CT}$, and the severity of the therapeutic pathomorphosis. Most - 20 (74.1\%) patients in the postoperative period received prophylactic chemotherapy, on average, within $5.7 \pm$ 0.17 months.

A complete response to the ongoing chemotherapy treatment was achieved in $3(8.6 \%)$ of 35 patients, in 19 $(54.3 \%)$ - a partial effect, stabilization - in 10 (28.6\%) patients. Against the background of chemotherapy in 3 $(8.6 \%)$ patients, the progression of the disease in the form of an increase in metastases by $20-25 \%$ was established. These patients were operated on after 2-3 courses of chemotherapy. The maximum effect of preoperative chemotherapy was achieved in patients 
with bilobar liver damage who received combinations with oxaliplatin - in $22(62.9 \%)$ cases. Elevated CEA levels before the start of preoperative chemotherapy were observed in $28(80.0 \%)$ patients. The success of preoperative chemotherapy was accompanied by a decrease in the CEA level in all patients with an objective effect and in $6(60.0 \%)$ of 10 patients with stabilization.

In most cases, the side effects of chemotherapy were clinically insignificant and did not exceed I - II degrees. Grade III - IV side effects were associated with $18(5.4 \%)$ treatment courses in $12(20 \%)$ patients. The greatest clinical significance were neutropenia, diarrhea, and palmar-plantar syndrome. There were no cases of discontinuation of chemotherapy due to unacceptable toxicity. At the same time, these complications did not affect the timing of surgical intervention in patients. To date, 32 patients have been followed up for 6-26.4 months, with an average followup time of 12.5 months and a median follow-up of 11.2 months. In $5(15.6 \%)$ patients, progression was established, which caused the death of one patient after 6 months. after extended hemihepatectomy, the rest of the patients are alive. The one-year progression-free survival rate was $84.4 \%$.

\section{Conclusion.}

To date, treatment of CRC with liver metastases does not have uniform standards, no unified tactics has been developed for this category of patients. The modern literature does not fully reflect the issues related to the possibilities of improving treatment results in patients with liver metastases, as well as the advantages of preoperative chemotherapy. In our studies, preoperative chemotherapy in 35 patients with CRC with liver metastases demonstrated a high frequency of objective effects - in $22(62.9 \%)$ patients, stabilization was noted in $10(28.6 \%)$ cases. With bilobar liver metastases and the use of oxaliplatincontaining regimens, partial regression was $62.9 \%$. Side effects in most cases were clinically insignificant, no deaths were observed. There was also no effect of preoperative chemotherapy on the incidence of postoperative complications. The results obtained demonstrate the possibility of performing extended surgical operations in the majority of CRC patients with multiple liver metastases.

\section{REFERENCES}

1.Assessorova Yu.Yu., Kireev G.V., Balenkov $\mathrm{O} . \mathrm{Yu}$. The most important modern trends in cancer incidence in different countries (review) // Journal of Theoretical and Clinical Medicine. -2009. -№2. -P.7781.

2.Balachandran V.P., Arora A., Gönen M. et al. A validated prognostic multigene expression assay for overall survival in resected colorectal cancer liver metastases // Clin. Cancer. Res. -2016. -V.22. -P.25752582.

3.Balenkov O.Yu., Yuldasheva D.Yu., Kireev G.V., Kamishov S.V. Study of oncological morbidity in the population of Tashkent // Journal of Theoretical and Clinical Medicine. -2007. -№ 3. -P.90-92.
4.Bazin I.S., Mamontov K.G. Modern approaches to chemotherapy in the complex treatment of localized colon cancer // Oncological Coloproctology. -2011. №2. -P.27-36.

5.Feo L., Polcino M., Nash G.M. Resection of the Primary Tumor in Stage IV Colorectal Cancer: When Is It Necessary? // Surg. Clin. North. Am. -2017. -V.97. -P.657-669.

6.Jones R.P., Brudvik K.W., Franklin J.M., Poston G.J. Precision surgery for colorectal liver metastases: Opportunities and challenges of omics-based decision making // Eur. J. Surg. Oncol. -2017. -V.43. -P.875883.

7.Kamishov S.V. Mechanisms of immune disorders in patients with ovarian cancer receiving chemotherapy and their dynamics during immunotherapy // Eurasian Oncological Journal, -2018 -P. 563-576

8.Kamishov S.V. Modern immunopharmacotherapy in the complex treatment of cervical cancer // Bulletin of Science and Education 2018 -V.2 (6 (42)), -P. 57-61

9.Kamishov S.V., Pulatov D.A., Nishanov D.A., Yuldasheva N.Sh. Influence of the expression level of tumor markers on the results of treatment of patients with cervical cancer who received concomitant immunotherapy // Eurasian Oncological Journal 5 (1), 2017-P. 68-76

10.Kamishov S.V., Pulatov D.A., Yusupova N.B., Niezova Sh.Kh. The state of immunoreactivity of patients with cervical cancer against the background of extracorporeal immunopharmacotherapy // Bulletin of the National. medical surgeon. center them. N.I. Pirogov 13 (1), -P. 98-102

11.Kamishov S.V., Pulatov D.A.Supportive immunotherapy in complex treatment of patients with oncogynaecological diseases //The scientific heritage 2017 -V.18 (18), 23-27

12.Kamyshov S.V., Nishanov D.A., Pulatov D.A., Yuldasheva N.S. //Izuchenie markerov apoptoza, proliferacii i angiogeneza u bol'nyh rakom jaichnika, poluchivshih soprovoditel'nuju immunoterapiju [The study of markers of apoptosis, proliferation and angiogenesis in patients with ovarian cancer who received accompanying immunotherapy]. Zlokachestvennye opuholi [Malignant tumors], 1, 84-91

13.Kamyshov S.V., Pulatov D.A., Nishanov D.A., Yuldasheva N.S., Yusupova N.B. Znachimost'ocenki molekuljarno-biologicheskih onkomarkerov $\mathrm{V}$ soprovoditel'noj immunoterapii pri rake shejki matki [Significance of the assessment of molecular biological tumor markers in accompanying immunotherapy for cervical cancer]. Onkologija i radiologija Kazahstana [Oncology and radiology of Kazakhstan], 2017 V.2 -P. 45-48

14.Kamyshov S.V., Pulatov D.A., Yuldasheva N.S. Ispol'zovanie metodov gravitacionnoj hirurgii krovi v kompleksnom lechenii bol'nyh rakom jaichnika [The use of gravitational blood surgery methods in the complex treatment of patients with ovarian cancer]. Vestnik Nacional'nogo mediko-hirurgicheskogo centra im. NI Pirogova BBBulletin of the National Medical and Surgical Center after Ni Pirogov], -201712 (1), -P. 
52-56Nigri G., Petrucciani N., Ferla F. et al. Neoadjuvant chemotherapy for resectable colorectal liver metastases: what is the evidence? Results of a systematic review of comparative studies // Surgeon. 2015. -V.13. -P.83-90.

15.Nordlinger B., Sorbye H., Glimelius B. et al. EORTC liver metastases intergroup randomized phase III study 40983: long-term survival results // J. Clin. Oncol. -2012. -V.30 (Sup.). -Abs.3508.

16.Oxenberg J., Papenfuss W., Esemuede I. et al. Multidisciplinary cancer conferences for gastrointestinal malignancies result in measureable treatment changes: a prospective study of 149 consecutive patients // Ann. Surg. Oncol. -2015. -V.22. -P.1533-1539.

17.Pulatov D.A., Ibragimov Zh.M., Kamishov S.V. Comparative assessment of the toxicity of treatment of patients with chemoresistant colorectal cancer // Oncology and Radiology of Kazakhstan -2018 V.44 (2), -P. 58-61

18.Roberts K.J., White A., Cockbain A. et al. Performance of prognostic scores in predicting long- term outcome following resection of colorectal liver metastases // Br. J. Surg. -2014. -V.101. -P.856-866.

19.Sekacheva M.I., Polishchuk L.O., Bagmet N.N., Skipenko O.G. Results of surgical treatment of metastatic colorectal cancer after drug therapy with the addition of bevacizumab // Modern Oncology. -2012. V.14. -№2. -P.38-41.

20.Tillyashaikhov M.N., Kamishov S.V. Features of the cellular status of immunity in patients with cervical cancer European science, 2018 No. 5 (37) P.75-79.

21.Tillyashaikhov M.N., Kamishov S.V. Features of the humoral status of immunity in patients with cervical cancer // Materials of the conference International scientific review of the problems and prospects of modern science and education 2018 -p. 8487

22.Vozdvizhensky M.O., Dudko S.M. Modern approaches to resection of liver metastases in colorectal cancer // Vestnik Ross. military med. academy. -2012. -№ 1. -V.37. -P.291-295.

\title{
STEM CELLS IN BREAST CANCER: \\ THE ROLE OF GENDER STEROID RECEPTORS
}

\author{
DOI: 10.31618/ESU.2413-9335.2020.1.77.959 \\ Izrailbekova $\mathbf{K}$. \\ Republican Specialized Scientific and Practical Medical Center \\ of Oncology and Radiology of the Ministry \\ of Health of the Republic of Uzbekistan
}

\section{СТВОЛОВЫЕ КЛЕТКИ РАКА МОЛОЧНОЙ ЖЕЛЕЗЫ: РОЛЬ ПОЛОВЫХ СТЕРОИДНЫХ РЕЦЕПТОРОВ}

Израильбекова К.

Республиканский специиализированный научно-практический медицинский центр онкологии и радиологии Министерства здравоохранения Республики Узбекистан

\section{SUMMARY}

Breast cancer (BC) is the most common cancer among women, and current treatments available often have high success rates. However, $\mathrm{BC}$ can acquire drug resistance and sometimes relapse. Current knowledge about the most aggressive forms of $\mathrm{BC}$ indicates the role of specific cells with stem properties located in $\mathrm{BC}$, the so-called "BCSCs" (Brest cancer stem cells). The role of BCSCs in cancer formation, growth, invasiveness, therapy resistance, and tumor recurrence is becoming increasingly evident. The growth and metastatic properties of BCSCs are regulated in a variety of ways that are only partially known. Sex steroid receptors (SSRs), which are involved in the etiology and progression of $\mathrm{BC}$, promote the proliferation, dedifferentiation and migration of BCSCs. However, the literature contains incomplete information about their roles. In particular, there are conflicting findings regarding the expression and role of classic BC hormone biomarkers such as estrogen receptor alpha $(\mathrm{ER} \alpha)$, together with scanty, albeit promising, information on the properties of ER-beta (ER $\beta)$ and androgen receptor (AR) that control pathways of transduction in BCSC. In this review, we will discuss the role that SRs expressed in BCSCs play in BC progression and relapse, and how these findings have opened up new therapeutic options.

These cells are predictors of $\mathrm{BC}$ and promising new therapies are being developed to target these cells and improve $\mathrm{BC}$ recurrence.

\section{PЕЗЮМЕ}

Рак молочной железы $\left(\mathrm{PMЖ}_{(\text {рус) }}\right.$, ВС (англ) $)$ является наиболее распространенным раком среди женщин, и современные доступные методы лечения часто имеют высокие показатели успеха. Тем не менее, ВС может приобрести лекарственную устойчивость, а иногда и рецидив. Современные знания о наиболее агрессивных формах ВС указывают на роль специфических клеток со стволовыми свойствами, расположенных в ВC, так называемых « стволовых клеток PMЖ » (BCSCs -Brest cancer stem cells). Pоль BCSC в формировании рака, росте, инвазивности, резистентности к терапии и рецидиве опухоли 